\title{
Anosmia as the initial presentation of neurosarcoidosis
}

Lakshman Arcot Jayagopal, MD, and Gloria von Geldern, MD

Neurology ${ }^{\circledR}$ 2018;91:1020-1021. doi:10.1212/WNL.0000000000006582
Correspondence

Dr. von Geldern

vgeldern@uw.edu

Figure MRI brain
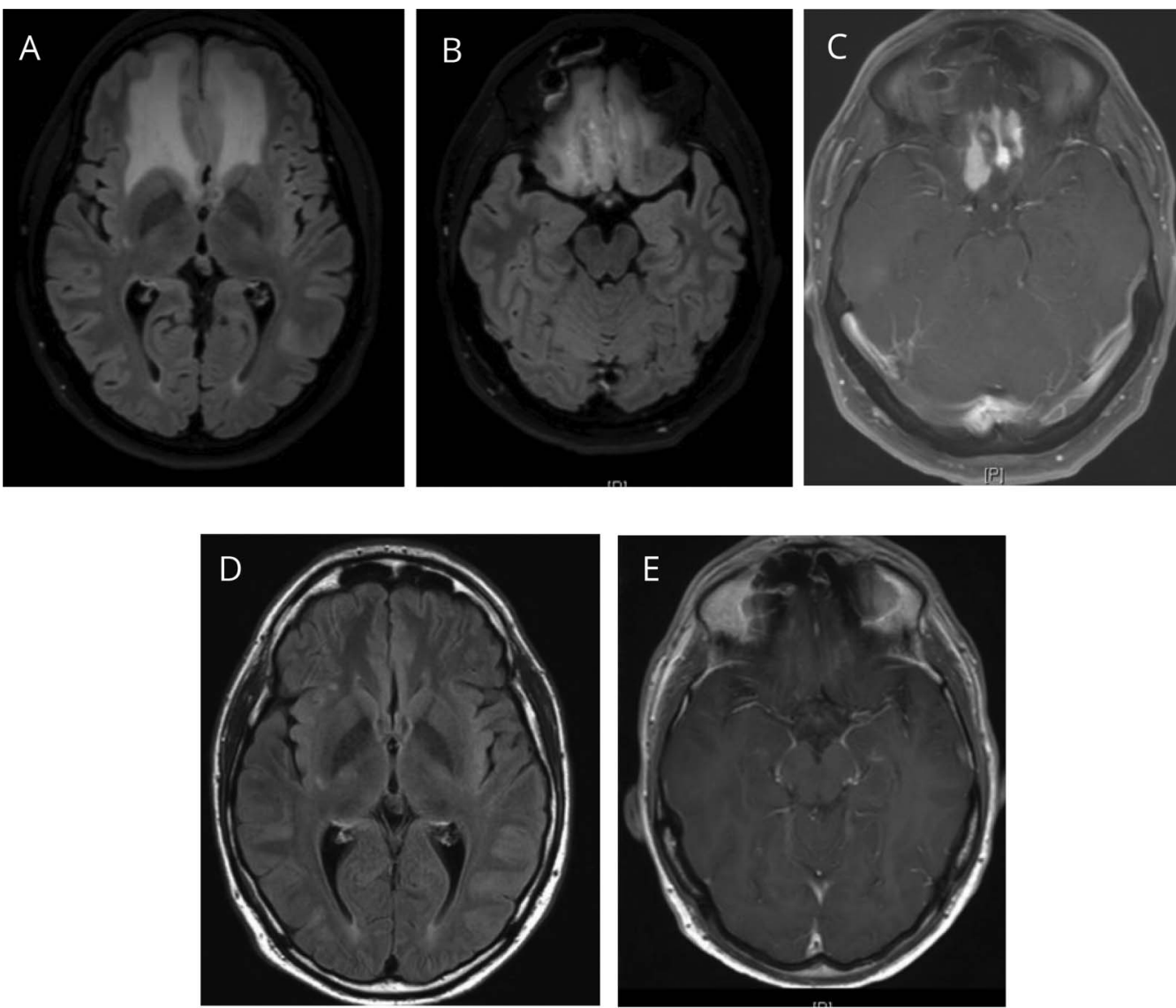

Axial fluid-attenuated inversion recovery MRI (A, B) with extensive vasogenic edema in the inferior anterior medial frontal lobes and axial T1-weighted contrast images $(C)$ show bilateral frontal pial and parenchymal enhancement. Seven months after treatment (D, E) shows resolution of the vasogenic edema and enhancement, respectively.

A 35-year-old man presented with progressive anosmia and no other complaints or findings. MRI brain showed extensive bifrontal edema and enhancement (figure, A-C). In retrospect, 7 years prior he had a neck mass with granulomata on biopsy, but had never received treatment for sarcoidosis. Clinical symptoms and MRI abnormalities improved (figure, D and E) with oral prednisone and methotrexate and he was diagnosed with probable neurosarcoidosis. Neurosarcoidosis is a rare etiology of anosmia but needs to be considered as a differential consideration. ${ }^{1}$ Anosmia in sarcoidosis is caused by an obstructed nose or neurosarcoidosis of the olfactory epithelium, bulb, or tract. ${ }^{2}$ 


\section{Author contributions}

L. Arcot Jayagopal: drafting/revising the manuscript, accepts responsibility for conduct of research and final approval. G. von Geldern: drafting/revising the manuscript, data acquisition, study concept or design, analysis or interpretation of data, accepts responsibility for conduct of research and final approval.

\section{Study funding}

No targeted funding reported.

\section{Disclosure}

The authors report no disclosures relevant to the manuscript. Go to Neurology.org/N for full disclosures.

\section{References}

1. Kieff DA, Boey H, Schaefer PW, Goodman M, Joseph MP. Isolated neurosarcoidosis presenting as anosmia and visual changes. Otolaryngol Head Neck Surg 1997;117: S183-S186.

2. Landis BN, Dubach P, Caversaccio MD. Anosmia and sarcoidosis. Am J Med 2011; 124:e25; author reply e27.

\section{Subspecialty Alerts by E-mail!}

Customize your online journal experience by signing up for e-mail alerts related to your subspecialty or area of interest. Access this free service by clicking on the "My Alerts" link on the home page. An extensive list of subspecialties, methods, and study design choices will be available for you to choose from—allowing you priority alerts to cutting-edge research in your field!

\section{Did You Know...}

... you can browse by subspecialty topics on Neurology.org?

Go to: Neurology.org and click on "Topics" in the top navigation bar.

\section{Sign Up for the AAN's Axon Registry}

The AAN encourages its US members to show their interest in participating in the Axon Registry ${ }^{\circledR}$ by signing up today.

Use the Axon Registry to:

- Simplify reporting requirements under MACRA’s Quality Payment Program and avoid penalties while reducing your administrative burden

- Meet your MOC Part IV requirements and waive up to eight credits of Part II Self-Assessment

- Choose from 22 AAN neurology-specific quality measures that fit your practice

- Use data to understand your practice and identify where improvements can be made to patient care

- Manage your patients at a population level; look at a specific group of patients based on conditions, risk factors, demographics or outcome

- Demonstrate your value to payers when negotiating reimbursement

- Enjoy multi-year, fee-free access when you sign the agreements and integrate your EHR with the registry

Learn more at AAN.com/view/Axon and send your questions to registry@aan.com. 


\section{Neurology}

\section{Anosmia as the initial presentation of neurosarcoidosis \\ Lakshman Arcot Jayagopal and Gloria von Geldern \\ Neurology 2018;91;1020-1021 \\ DOI 10.1212/WNL.0000000000006582}

This information is current as of November 26, 2018

\begin{tabular}{|c|c|}
\hline $\begin{array}{l}\text { Updated Information \& } \\
\text { Services }\end{array}$ & $\begin{array}{l}\text { including high resolution figures, can be found at: } \\
\text { http://n.neurology.org/content/91/22/1020.full }\end{array}$ \\
\hline References & $\begin{array}{l}\text { This article cites } 2 \text { articles, } 0 \text { of which you can access for free at: } \\
\text { http://n.neurology.org/content/91/22/1020.full\#ref-list-1 }\end{array}$ \\
\hline Subspecialty Collections & $\begin{array}{l}\text { This article, along with others on similar topics, appears in the } \\
\text { following collection(s): } \\
\text { All Clinical Neurology } \\
\text { http://n.neurology.org/cgi/collection/all_clinical_neurology } \\
\text { All Immunology } \\
\text { http://n.neurology.org/cgi/collection/all_immunology } \\
\text { MRI } \\
\text { http://n.neurology.org/cgi/collection/mri }\end{array}$ \\
\hline Permissions \& Licensing & $\begin{array}{l}\text { Information about reproducing this article in parts (figures,tables) or in } \\
\text { its entirety can be found online at: } \\
\text { http://www.neurology.org/about/about_the_journal\#permissions }\end{array}$ \\
\hline Reprints & $\begin{array}{l}\text { Information about ordering reprints can be found online: } \\
\mathrm{http} / / / \mathrm{n} \text {.neurology.org/subscribers/advertise }\end{array}$ \\
\hline
\end{tabular}

Neurology ${ }^{\circledR}$ is the official journal of the American Academy of Neurology. Published continuously since 1951, it is now a weekly with 48 issues per year. Copyright (O 2018 American Academy of Neurology. All rights reserved. Print ISSN: 0028-3878. Online ISSN: 1526-632X.

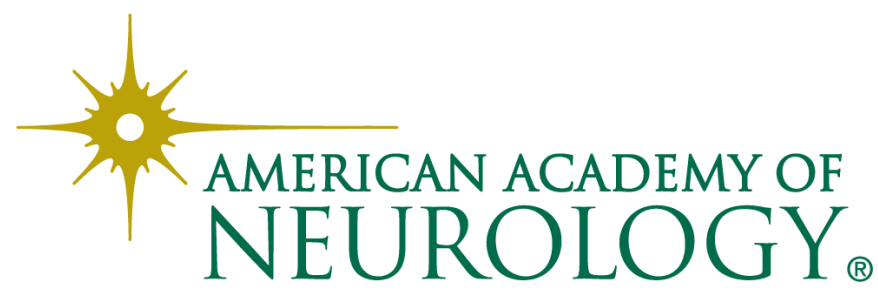

